\title{
The Characterization of the Heating Properties of Briquettes of Coal and Rice Husk.
}

\author{
Ikelle Issie Ikelle, Anyigor Chukwuma \& Ogah Sule Philip Ivoms \\ Department Of Industrial Chemistry, Ebonyi State University Abakaliki, Pmb 053, Nigeria.
}

\begin{abstract}
In this work, smokeless briquettes of various compositions were produced using coal and rice husk, starch was used as the binder while $\mathrm{Ca}\left(\mathrm{OH}_{2}\right)$ was the desulphurizing agent. The briquettes were produced in the following ratio of mixtures; coal and rice husk 100:0, 80:20, 60:40, 40:60, 20:80 and 0:100 respectively. The proximate analysis of the raw coal sample showed ash content $19.12 \%$, moisture content $6.25 \%$, volatile matter $41.12 \%$, fixed carbon $33.51 \%$ and calorific value $117 \mathrm{KJ} / \mathrm{g}$. the rice husk had the following values ash content $7.53 \%$, moisture content $10.48 \%$, volatile matter $68.74 \%$, fixed carbon $13.25 \%$ and calorific value $65.24 \mathrm{KJ} / \mathrm{g}$. The prepared briquettes were sun dried for seven days, subjected to various tests to assess their fuel quality. Of the briquettes produced, the 60\% coal: $40 \%$ rice husk briquette showed the following values; ash content $20.26 \%$, fixed carbon $50.06 \%$, moisture content $4.42 \%$, density $0.414 \mathrm{~g} / \mathrm{cm}^{3}$, volatile matter $25.26 \%$, porosity index $40.7 \%$, calorific value $142.86 \mathrm{KJ} / \mathrm{g}$, water boiling test 2.15 minutes, burning time 20.43 minutes, ignition time 33.67 seconds and sulphur content 4.69\%. The briquette showed improved properties with regards to combustible property when compared to the other briquettes produced with the same binder but different compositions.
\end{abstract}

Key words: briquette, biomass, coal, rice husk, starch.

\section{Introduction}

Many of the developing countries produce huge quantities of agro residues but they are used inefficiently causing extensive pollution to the environment. Rice husks are residues of rice harvesting and processing operations for which rather minimum utilization outlets have been found in Nigeria despite its vast potentials. Rice husk is the outermost layer of the paddy grain that is also called rice hull. It is separated from the brown rice in rice milling. Burning rice husk produces rice husk ash, if the burning process is incomplete carbonized rice husk is produced. Around 20\% of the paddy weight is husk. In 2008 the world paddy production was 661 million tons and consequently 132 million tons of rice husk were also produced. While there are some uses of rice husk, it is still often considered a waste product in the rice mill and therefore often either burned or dumped on waste lands. Husk has a high calorific value and therefore can be used as a renewable fuel. Rice husk is produced in the first step in the milling process when the husk is removed from the grain in the husking stage of the rice mill (Beloilo, 2005).

Coal is burned in coal-fired plants to produce energy in the form of electricity. Domestically, coal is burnt in un-vented stoves producing heat energy for cooking and heating up homes. Over the years, it has been recognized that certain impurities in coal can have a significant impact on the types of emissions produced during coal combustion. However, various processes employed in converting coal into more useful forms emit considerable amounts of pollutants such as $\mathrm{SO}_{2}, \mathrm{NO}_{\mathrm{x}}, \mathrm{CH}_{4}$, etc (Rahman et al., 2000).

A briquette is a block of compressed coal, biomass or charcoal dust that is used as fuel (Grainger et al., 1981). In the production of briquettes, the materials can be compressed without addition of adhesive, while in others adhesive materials called binders are added to assist in holding the particles of the material together depending on the type of raw material used for the production (Bhattacharya, 1985).

Bio-coal briquette is a type of solid fuel prepared by compacting pulverized coal, biomass, binder and sulphur fixation agent. The high pressure involved in the process ensures that the coal and the biomass particles are sandwiched and adhere together, as a result they do not separate during transportation, storage and combustion. During combustion, the co-combustion of the coal and the biomass gives a better combustion performance and reduces pollutant emission i.e bio-coal briquette has a favourable ignition, better thermal efficiency, emits less dust and soot (Somchai et al., 1988). Briquetting can be regarded as a waste control measure. Depending on the material of interest, briquetting can be used to provide fuel source, as a preventive measure to many ecological problem. Certain materials like coal, agricultural waste such as rice husk, corn cob, paper and saw dust can be briquetted to serve as cooking fuel (Bhattacharya, 1985).

Furthermore, the presence of sulphur fixation agent otherwise known as desulfurizing agent ensures that most of the sulphur content of the coal is fixed into the ash instead of being liberated into the atmosphere as $\mathrm{SO}_{2}$ (Somchai et al., 1988).

$$
\mathrm{CaO}_{(\mathrm{s})}+\mathrm{SO}_{2(\mathrm{~g})}+1 / 2 \mathrm{O}_{2(\mathrm{~g})}
$$


The ash of bio-coal has been shown to be effective for soil treatment and enrichment. However, preserving the forest resources by substituting fuel wood with bio-coal, along with the use of the ash from this briquette for soil treatment will compensate for fossil carbon emitted by the coal component of the briquette. Therefore bio-coal is considered to be a clean technology (Kwong et al., 2007).

\section{Objective Of The Study}

To produce smokeless briquettes from coal and rice husk using starch as binder. To carryout proximate analysis of the briquettes to determine their combustible properties. To compare the results so as to determine the briquette composition with best combustible quality.

\section{MATERIALS}

Pulverised coal, rice husk, bitumen, calcium hydroxide, electronic weighing machine, manual briquetting machine, electric milling machine, stop watch, muffle furnace, oxygen bomb calorimeter machine model-OSK 100A.

\section{Preparation of the coal sample}

\section{METHODS}

The coal sample was sun dried for five days to reduce its moisture content, broken into smaller sizes using a hammer. The coal samples were then ground in an electric milling machine to pass through $1 \mathrm{~mm}$ sieve and stored.

\section{Preparation of the biomass}

The biomass (rice husk) was collected, sun dried for five days to reduce the moisture content, ground and sieved through $1 \mathrm{~mm}$ sieve and stored.

\section{Preparation of the briquette samples}

The briquettes were produced using a manual hydraulic briquetting machine with three cylindrical moulds. Briquettes of coal and rice husk of different compositions were produced with a specific amount of $\mathrm{Ca}(\mathrm{OH})_{2}$ added as desulphurizing agent based on the quantity of coal added, starch paste formed with hot water was added as binder. Specific quantity of water was added and mixed properly. The pressure was maintained at $5 \mathrm{MPa}$ for 15 minutes and was allowed to stand for 5 minutes before removal from the mould. After production, the briquettes were sun dried for 7days before analysis.

\section{PROXIMATE ANALYSIS OF SAMPLES}

Calorific value: The calorific value of the raw rice husk, raw coal and the briquettes were determined using Oxygen Bomb Calorimeter of model-OSK 100A. The calorific value $(\mathrm{KJ} / \mathrm{g})$ of the samples under test was calculated from the temperature rise VI in the calorimeter vessel and the mean effective heat capacity of the system. (Sumner et al., 1983)

$\mathrm{VI}=(\mathrm{Ee}+\mathrm{W} 1) \mathrm{TR}-\mathrm{C}) / \mathrm{S} \times 4.1868$

Where $\mathrm{Ee}$ is the water equivalent of the calorimeter $(581 \mathrm{~g}), \mathrm{W}_{1}=$ quantity of water in the vessel, TR = Temperature rise ${ }^{\circ} \mathrm{C}, \mathrm{C}=$ correction factor from ignition $154 \mathrm{Cal}, \mathrm{S}=$ weight of sample in grams $(\mathrm{g})$.

Moisture content: The moisture contents of the raw coal, rice husk and briquettes were determined. A portion $(2 \mathrm{~g})$ each of the samples was weighed out in a wash glass. The samples were placed in an oven for 2 hours at $105^{\circ} \mathrm{C}$. The moisture content was determined using:

$\mathrm{MC}=\frac{\mathrm{W}_{1}}{\mathrm{~W}_{1}}-\mathrm{W}_{2} \times 100$

$\mathrm{W}_{1}=$ Initial weight, $\mathrm{W}_{2}=$ Weight after drying

Ash content: The ash contents of the raw coal, rice husk and briquettes were also determined. A Portion (2g) were placed in a preweighed porcelain crucible and transferred into a preheated muffle furnace set at a temperature of $600^{\circ} \mathrm{c}$ for 1 hour after which the crucible and its contents were transferred to a desiccator and allowed to cool. The crucible and its content were reweighed and the new weight noted. The percentage ash content was calculated thus:

$\mathrm{AC}(\%)=\left(\mathrm{W}_{2} / \mathrm{W}_{1}\right) \times 100$.

$\mathrm{W}_{1}=$ Original weight of dry sample, $\mathrm{W}_{2}=$ Weight of ash after cooling.

Volatile matter: The volatile matter of the raw coal, rice husk and briquettes were also determined. A portion $(2 \mathrm{~g})$ of the sample was heated to about $300^{\circ} \mathrm{C}$ for 10 minutes in a partially closed crucible in a muffle furnace. 
The crucible and its content were retrieved and cooled in a desiccator. The difference in weight was recorded and the volatile matter was calculated thus:

$\mathrm{VM}=\left(\underline{\mathrm{W}}_{1}-\mathrm{W}_{2}\right) \times 100$

$\mathrm{W}_{1}$

$\mathrm{W}_{1}=$ Original weight of the sample. $\mathrm{W}_{2}=$ Weight of sample after cooling.

Fixed carbon: The fixed carbon of the raw coal, rice husk and briquettes were also determined. The fixed carbon was determined using the formula

$\mathrm{FC}(\%)=100-(\% \mathrm{VM}+\% \mathrm{AC}+\% \mathrm{MC})$

Where VM $=$ Volatile matter, $\mathrm{AC}=$ Ash content, $\mathrm{MC}=$ Moisture content $($ ASTM 1992).

Density: A calibrated graduated cylinder was used for the estimation of destiny. The cylinder was packed with the samples and compacted. The density was thus calculated thus:

Density $\left(\mathrm{g} / \mathrm{cm}^{3}\right)=$ Mass $(\mathrm{g})$

$$
\text { Volume }\left(\mathrm{cm}^{3}\right)
$$

\section{Total Sulphur Content:}

The different samples of the briquettes was pulverized, $1 \mathrm{~g}$ of the finely powdered samples was mixed with $5 \mathrm{~g}$ of $\mathrm{Na}_{2} \mathrm{NO}_{3}$ and $0.2 \mathrm{~g}$ of $\mathrm{NaNO}_{3}$ in a crucible. The mixture was preheated at $400^{\circ} \mathrm{C}$ for 30 minutes in an electric muffle furnance and then fused at $950^{\circ} \mathrm{C}$, after fussion, the crucible was allowed to cool and was placed on its side in a $150 \mathrm{~cm}^{3}$ beaker. $\mathrm{HCl}$ was added to neutralize the $\mathrm{Na}_{2} \mathrm{CO}_{3}$ and boiled to precipitate the sulphate by treating with $\mathrm{BaCl}_{2}$. The precipitate treated with drops of $\mathrm{HF}$ and $\mathrm{H}_{2} \mathrm{SO}_{4}$, ignited and weighed again. Total sulphur is determined by the expression (Jackson, 1958).

$$
\% \text { sulphur }=\underline{\mathrm{BaSO}}_{4}(\mathrm{~g}) \times 13.7 \times 100
$$

Weight of sample

Porosity Index: The porosity of the briquettes was determined based on the amount of water each sample was able to absorb. The porosity index was calculated as the ratio of the mass of water absorbed to the mass of the sample immersed in the water (Montgomery, 1978).

Porosity Index $=$ Mass of water absorbed $\times 100$

Ignition time (secs)

$$
\text { Mass of the sample }
$$

The different samples were ignited at the edge of their bases with a burnsen burner. The time taken for each briquette to catch fire was recorded as the ignition time using a stopwatch.

\section{Burning time (mins)}

This is the time taken for each briquette sample to burn completely to ashes. Subtracting the time is turned to ashes completely from the ignition time gives the burning rate.

Burning rate $=$ Ashing time - Ignition time.

\section{Water boiling test (mins)}

This was carried out to compare the cooking efficiency of the briquettes .It measures the time taken for each set of briquettes to boil an equal volume of water under similar conditions.100g of each briquette sample was used to boil $250 \mathrm{ml}$ of water using small stainless cups and domestic briquette stove. (Kim et al., 2001).

\section{Results}

Table 1. The results of proximate analysis of the raw coal and rice husk.

\begin{tabular}{|l|l|l|l|l|l|}
\hline Samples & $\begin{array}{l}\text { Moisture } \\
\text { content }(\%)\end{array}$ & $\begin{array}{l}\text { Volatile } \\
\text { matter }(\%)\end{array}$ & Ash content $(\%)$ & $\begin{array}{l}\text { Fixed } \\
\text { carbon(\%) }\end{array}$ & $\begin{array}{l}\text { Calorific value } \\
(\mathrm{KJ} / \mathrm{g})\end{array}$ \\
\hline Coal & 3.25 & 20.12 & 19.12 & 57.51 & 117.18 \\
\hline Rice husk & 8.48 & 42.14 & 7.53 & 41.85 & 65.24 \\
\hline
\end{tabular}

Table 2. Results of proximate analysis of the various briquette samples

\begin{tabular}{|l|l|l|l|}
\hline Briquette sample (\%) & $\begin{array}{l}\text { Moisture content } \\
(\%)\end{array}$ & Density $\left(\mathrm{g} / \mathrm{cm}^{3}\right)$ & Sulphur content (\%) \\
\hline $100 \% \mathrm{CD}$ & 2.78 & 0.724 & 6.21 \\
\hline $80 \% \mathrm{CD} 20 \% \mathrm{RH}$ & 3.37 & 0.594 & 5.52 \\
\hline $60 \% \mathrm{CD} 40 \% \mathrm{RH}$ & 4.42 & 0.414 & 4.69 \\
\hline $40 \% \mathrm{CD} 60 \% \mathrm{RH}$ & 4.55 & 0.334 & 4.42 \\
\hline $20 \% \mathrm{CD} 80 \% \mathrm{RH}$ & 5.68 & 0.274 & 4.14 \\
\hline $100 \% \mathrm{RH}$ & 6.95 & 0.224 & 3.45 \\
\hline
\end{tabular}


Key- $\mathrm{CD}=$ Coal dust, $\mathrm{RH}=$ Rice husk

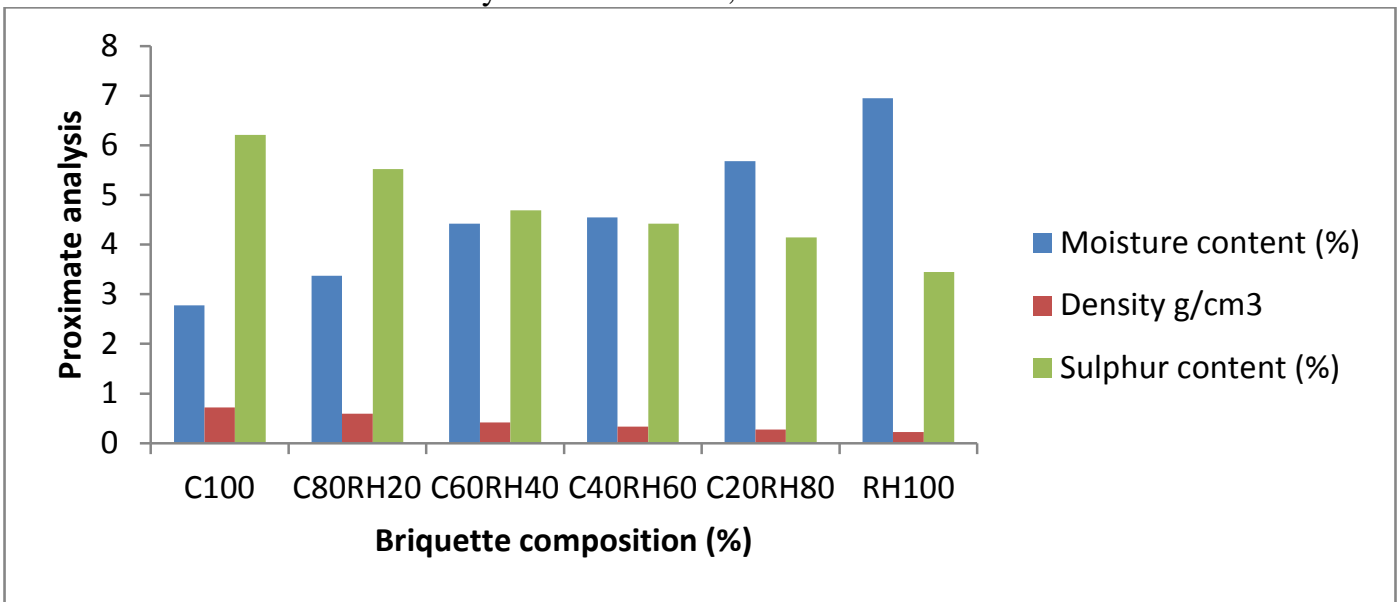

Fig. 1. The proximate analysis of the various compositions of briquette samples.

Table 3. Results of proximate analysis of the various briquette samples

\begin{tabular}{|l|l|l|l|l|}
\hline Briquette sample (\%) & Volatile matter (\%) & Ash content (\%) & Fixed carbon (\%) & $\begin{array}{l}\text { Porosity index } \\
(\%)\end{array}$ \\
\hline $100 \%$ CD & 13.40 & 22.06 & 61.76 & 24.96 \\
\hline $80 \%$ CD 20\%RH & 21.13 & 21.79 & 53.71 & 33.66 \\
\hline $60 \%$ CD 40\%RH & 25.26 & 20.26 & 50.06 & 40.76 \\
\hline $40 \%$ CD 60\%RH & 36.13 & 19.45 & 39.87 & 50.48 \\
\hline $20 \%$ CD 80\%RH & 43.86 & 18.91 & 31.55 & 62.52 \\
\hline $100 \%$ RH & 49.23 & 16.82 & 27.00 & 70.13 \\
\hline
\end{tabular}

Key- $\mathrm{CD}=$ Coal dust, $\mathrm{RH}=$ Rice husk

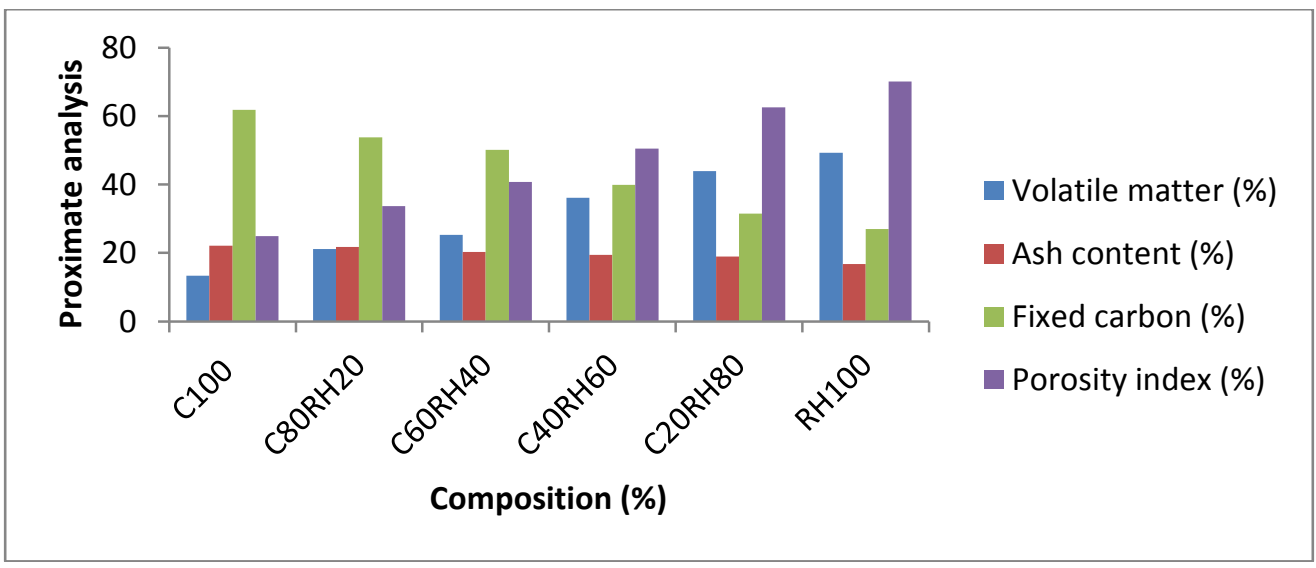

Fig.2 The plot of proximate analysis of the briquettes against composition.

Table 4. The results of the calorific values of the samples

\begin{tabular}{|l|l|}
\hline Briquette sample & Calorific values( $\mathrm{kj} / \mathrm{kg})$ \\
\hline $100 \% \mathrm{CD}$ & 164.34 \\
\hline $80 \% \mathrm{CD} 20 \% \mathrm{RH}$ & 151.51 \\
\hline $60 \% \mathrm{CD} 40 \% \mathrm{RH}$ & 142.86 \\
\hline $40 \% \mathrm{CD} 60 \% \mathrm{RH}$ & 126.25 \\
\hline $20 \% \mathrm{CD} 80 \% \mathrm{RH}$ & 108.09 \\
\hline $100 \% \mathrm{RH}$ & 90.23 \\
\hline
\end{tabular}

Key- $\mathrm{CD}=$ Coal dust, $\mathrm{RH}=$ Rice husk

Table 5. The result of burning rate, burning time and ignition time

\begin{tabular}{|l|l|l|l|}
\hline Briquette samples & Water boiling test $(\mathrm{min})$ & Burning time $(\mathrm{min})$ & Ignition time (secs) \\
\hline $100 \% \mathrm{CD}$ & 1.42 & 26.21 & 47.33 \\
\hline $80 \% \mathrm{CD} 20 \% \mathrm{RH}$ & 1.62 & 24.15 & 41.00 \\
\hline
\end{tabular}


The Characterization of the Heating Properties of Briquettes of Coal and Rice Husk.

\begin{tabular}{|l|l|l|l|}
\hline $60 \%$ CD40\%RH & 2.15 & 20.43 & 33.67 \\
\hline $40 \%$ CD60\%RH & 2.91 & 19.22 & 29.67 \\
\hline $20 \%$ CD80\%RH & 3.42 & 17.48 & 27.00 \\
\hline $100 \%$ RH & 4.12 & 16.17 & 23.33 \\
\hline
\end{tabular}

Key- $\mathrm{CD}=$ Coal dust, $\mathrm{RH}=$ Rice husk

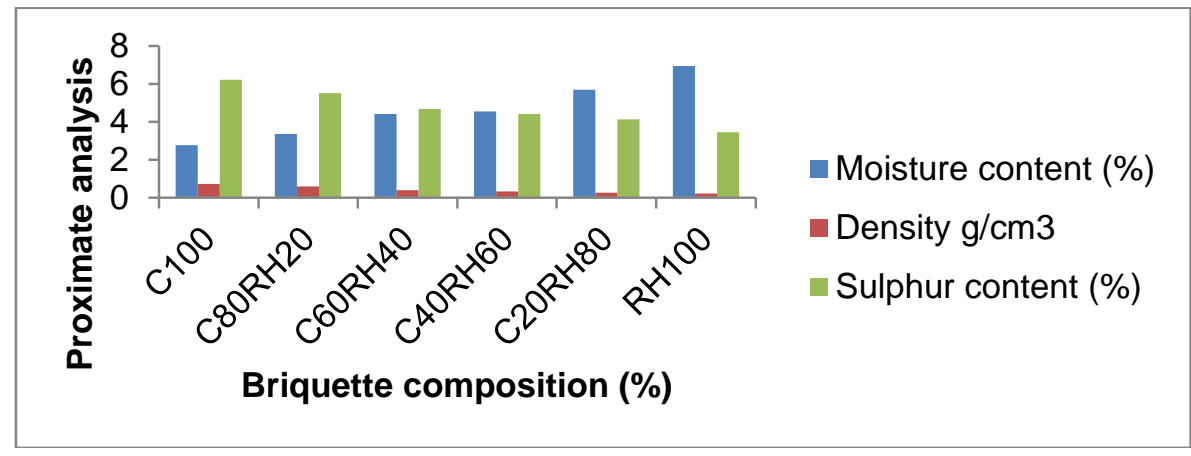

Fig.3 The plot of proximate analysis of the briquettes against composition.

\section{Discussions}

The proximate analysis show that moisture content values increased with the amount of rice husk added with $100 \%$ rice husk briquettes having the highest value because rice husk is more coarse than coal. The density decreased with addition of rice husk to the coal and $100 \%$ coal briquettes had the highest value since coal particles are much held together. The results of the sulphur content showed that $100 \%$ coal briquettes had the highest sulphur content but with the briquetting of coal and rice husk, increasing the amount of the sulphur fixing agent $\mathrm{Ca}(\mathrm{OH})_{2}$ the sulphur content decreases. The glucosidic bond of starch which is easily broken contributes to the easy ignitable qualities of the briquettes produced. The particles of rice husk are less bonded to each than coal particles, $100 \%$ rice husk briquettes generated more volatile matter upon heating than $100 \%$ coal briquettes. To reduce the volatile matter and make the briquettes more suitable for combustion the composition of coal and rice husk were varied to yield briquettes with reduced volatile matter. The results showed that briquettes of $100 \%$ rice husk had the highest values of moisture content when compared to other compositions of briquettes. The results also showed that the briquetting of coal and rice husk reduces the moisture content of the briquettes The result for porosity index showed that briquettes of biomass in which the particles are more adherred to each other will have a lower porosity index values than those with loose particles. Rice husk has more coarse loose particles unlike coal dust particles, as such the briquettes from mixture of coal and rice husk will have pores that will help in the passage of oxygen that is needed for combustion to take place. The calorific value (or heating value) is the standard measure of the energy content of a fuel. It is defined as the amount of heat evolved when a unit weight of fuel is completely burnt and the combustion products are cooled to $298 \mathrm{k}$. The ignition time of the briquettes shows that $100 \%$ rice husk briquettes are easily ignited unlike $100 \%$ coal briquettes. The blending of coal and rice husk produces briquette that ignites very fast, thereby solving the slow ignitability problem of coal briquettes. The water boiling test carried out on the briquettes showed that the briquettes made from blends of coal and rice husk briquettes burned faster than $100 \%$ coal briquettes and $100 \%$ rice husk briquettes. The differences in burning time for briquettes of $100 \%$ coal and the briquettes of $60 \%$ coal and $40 \%$ rice husk are not much, therefore blending will not only make the briquettes ignite very fast but will allow for longer cooking time.

\section{Conclusion}

In conclusion, bio-mass briquettes have drawn worldwide interest as an energy source because it does not negatively affect the environment. These bio-coal briquettes are very efficient since the quality of solid fuel depends on the following factors; providing sufficient heat as at time necessary, igniting easily without danger, generating less smoke and gases that are harmful to environment, generating less ash, as these constitute nuisance during cooking. The briquette sample $60 \%$ coal: $40 \%$ rice husk yielded optimum combustible values when compared with the other blends of briquettes.

\section{References}

[1]. American Society for Testing and Materials (ASTM), (1992). Annual Book of ASTM Standards, Petroleum Products, Lubricants and Fossil Fuels, New York, Section 5.50(12), pp. 210-218.

[2]. Belonio, A.T., (2005). Rice Husk Stove Handbook. Appropriate Technology Center, Department of Agricultural Engineering and Environmental Management, Iloilo City, Philippines, pp. 155-160. 
[3]. Bhattacharya, C., (1985). "Densified Biomass in Thailand: Potential, Status and Problems", Elsevier Applied Science Publishers, London, pp. 255-259.

[4]. Jackson, M.L., (1958). Soil Chemical Analysis, Prentice Hall Inc. Englewood Cliffs, New Jersey, pp. 134-320.

[5]. Kim, H., Kazuhiko, S. and Masayoshi, S., (2001). Biomass Briquette as a Technology for Desulphurizing and Energy Saving, Renewable Energy Journal, 8: 33-75.

[6]. Kwong, P.C.W., Wang, J.H. and Chao, C.W., (2007). Effect of Co-combustion of Coal and Rice Husk on the Combustion Performance and Pollutant Emission, Atmospheric Environment J., 17(4):7462-7468.

[7]. Montgomery, W.F., (1978). Standard Laboratory Test Methods for Coal and Coke in Analytical Methods for Coal and Coal Products, Academic Press, New York, pp. 194-224.

[8]. Rahman, A., Edwards, C.A. and Akbar, S.A., (2000). Effluent Gases from Coal Combustion-Effect on Environment. www.ssrn.com/abstract=209488 Retrieved on $12^{\text {th }}$ March 2012.

[9]. Somchai, O., Kunchana, B. and Duangporn, T., (1988). In-situ Desulfurization of Coal Briquettes by Lime, Department of Chemical Technology, Chulalondkorn University, Bangkok, pp. 5-10.

[10]. Sumner, H.R., Sumner, P.E., Harmnond, V.C. and Monroe, G.E., (1983). Indirect-Fired Biomass Furnace Test and Bomb Calorimeter Determinations, Trans. ASAE, 26(1): 238-241. 